\title{
Max Headroom: Discretionary Capital Buffers and Bank Risk
}

\author{
MARTIEN LUBBERINK ${ }^{\mathrm{a}}$
}

24th July 2020

\footnotetext{
${ }^{a}$ Corresponding Author: School of Accounting and Commercial Law, Victoria University of Wellington, PO Box 600, Wellington 6140, New Zealand. W: +64 4463 5968; M: +64 21 134 7500; F: +64 44635076. Email: martien.lubberink@vuw.ac.nz.

I thank Bogdan-Gheorghe Cicioc and Jérôme Legras, Antony Rich, as well as participants at the New Zealand Finance Colloquium, Auckland, 2020; the University of Melbourne Accounting and Finance Research Workshop, 2020; and the AFAANZ meetings, Melbourne, 2020 for useful comments. I thank Asma Jahan and Bastian Lubberink for data collection.
} 


\title{
Max Headroom: Discretionary Capital Buffers and Bank Risk
}

\begin{abstract}
This paper examines the association between discretionary capital buffers, capital requirements, and risk for European banks. The discretionary buffers are banks' own buffers, or headroom: the difference between reported and required capital. I exploit capital requirements data that banks started to disclose since the release of a 2015 European Banking Authority opinion. Results using detailed SREP and Pillar 2 data of the largest 99 European banks over 2013-2019 show that less headroom is associated with increased bank risk. An additional examination reveals a positive association between headroom and stress test results for banks subjected to the Single Supervisory Mechanism, a result that runs against supervisory requirements.
\end{abstract}

JEL classification: E58, G21, G32, M41.

Keywords: Banking, European Banks, Pillar 2 requirements, SREP. 


\section{Introduction}

Banks have significantly raised capital ratios since the onset of Global Financial Crisis. Common Equity Tier 1 ratios for large internationally operating banks are now close to 13 percent, which is significantly higher than a decade ago (BCBS, 2019a). Since 2011, European banks have doubled CET1 ratios to over 14 percent (EBA, 2012, 2019a).

Although the increase in bank capital ratios is an important result of regulatory initiatives since the Global Financial Crisis (GFC), they are not fully determined by formal capital requirements. For European banks in particular, a significant part of the increase in capital is the result of the Supervisory Review and Evaluation Process, or SREP (ECB, 2018). SREP capital requirements are jointly determined by the bank and its supervisor and add a layer of capital requirements over the primary, Pillar 1, capital requirements. SREP capital, also known as Pillar 2 capital, covers risks not covered by Pillar 1, which covers only credit risk, market risk, and operational risk.

Since 2015, European banks started disclosing Pillar 2 and SREP requirements, which is unprecedented. Before 2015 and outside Europe, banks and supervisors have kept (and still keep) these buffers out of the public eye. Access to these requirements allows me to better assess the true capital requirements.

Using a unique set of hand-collected Pillar 2 and SREP data from European banks for the years 2013-2019, I document a negative association between discretionary capital buffers and nondiscretionary, or required bank capital: increases in the latter go at the expense of the former. This negative association could just indicate that an increase of required capital captures all relevant bank risks, i.e. that bank-specific risks (which should drive the discretionary buffers) diminish when required capital increases. To assess if that is the case, I examine the association between discretionary bank buffers (or banks' own buffers, headroom) and bank risk. My results then show that diminished discretionary bank capital is associated with elevated risk. Yields on contingent convertible capital instruments (CoCos, or Additional Tier 1 capital), densities (the ratio of riskweighted assets to total assets), and the response to the March 2020 COVID-19 share price crash increase with declining levels of discretionary capital, while Z-scores decrease. These results hold, even after controlling for non-discretionary, required bank capital. 
An additional examination of European banks' responses to stress tests reveals a positive association between discretionary buffers and stress test results, that is, for banks that are subjected to the Single Supervisory Mechanism (SSM). SSM banks that perform poorly in EBA stress tests lower their discretionary buffers in post-stress test years, whereas supervisory guidance requires banks to use the stress test results to set, arguably strengthen, discretionary bank capital buffers. The positive association between discretionary buffers and stress test results is particularly strong for SSM banks during later sample years.

In all, my results document that discretionary buffers give way to formal, required buffers. The increase in required buffers lowers banks' discretionary (own) buffers or 'headroom'. The loss of headroom is associated with risk. The results of the stress test analysis then shows that the loss of headroom negatively affects risk mitigation. Consequently, my paper shows further limits of the effectiveness of bank capital requirements.

This study contributes to a growing literature that critically examines the effects of the postGFC bank regulation. Against a backdrop of research that advocates high capital ratios, see for example Admati et al. (2016), I examine bank-specific capital ratio requirements in relation to bank risk. The results show that lower discretionary buffers are associated with higher risk, even controlling for non-discretionary bank capital requirements.

I extend work of Gropp et al. (2016), Dautoviç (2019) and Goel et al. (2019), who document consequences of higher capital ratios in a post-GFC era. For example, I document how banks' discretionary buffers interact with capital requirements. I also contribute to research that demonstrates the diminishing effectiveness of capital requirements once banks achieve a certain capitalisation (BCBS, 2019b, Arnould et al., 2020). With access to data covering the years following the entry into force of Basel III, I extend work of EBA's Melis and Weissenberg (2019), who find no evidence of a link between bank characteristics and discretionary capital buffers. My evidence does show such evidence.

My results also contribute to the literature on stress testing (Acharya et al., 2014, Steffen, 2014), in that I document how European banks respond to stress test results. Instead of using stress test results to augment discretionary buffers, as prescribed and proposed by the EBA (EBA, 2018, 
2020), my results show that a significant number of banks that perform poorly in EBA stress tests fail to augment discretionary buffers, whereas one would expect a more prudent response from these banks.

My results are policy relevant. More than then a decade after the onset of GFC, regulators are calling for an increase in capital requirements (de Guindos, 2019, Brainard, 2019), while at the same time the gap between required and actual capital ratios are falling (EBA, 2019b, World Bank, 2019). Moreover, policy makers have started noticing that bank buffers serve conflicting interests: from a macro-prudential point of view there may be a need to draw down buffers in an economic downturn, whereas from a micro-economic, bank-specific, point of view such a drawing down is not warranted (Pablo Hernández de Cos, 2019). In addition, my data confirms existing studies on the poor performance of European banks (e.g. EBA (2019b)), while at the same time bank capital requirements have increased. These developments raise questions about the relevance of discretionary bank buffers (Pillar 2 and SREP), which this paper attempts to answer.

\section{Literature}

\subsection{Bank capital}

The recent literature covering bank capital predominantly focuses on levels of capital, albeit that views on the benefits and costs of bank capital vary. Where Mehran and Thakor (2011), Admati et al. (2016), Admati et al. (2017), Berger and Bouwman (2013), Thakor (2014), and Gambacorta and Shin (2016) highlight the benefits of high levels of bank capital, others express a more moderate position (e.g., Diamond and Rajan, 2001, Kashyap et al., 2008, DeAngelo and Stulz, 2013). The documented benefits of bank capital are: improved ability to survive and gain market share (Berger and Bouwman, 2013, Liu et al., 2013, BCBS, 2018), lending and debt funding (Bolton et al., 2016, Gambacorta and Shin, 2018), liquidity (Berger and Bouwman, 2009), market value (Mehran and Thakor, 2011), and higher GDP (Brooke et al., 2015, Homar and van Wijnbergen, 2017).

Views on how high capital requirements should be vary. Firestone et al. (2017) show that optimal capital ratios are between 13-25 percent of Risk-weighted assets. BCBS (2010) finds a optimal range of 9-15 percent, and the Minneapolis FED asserts that a minimum capital requirement 
of about 22 percent maximizes net benefits (FED Minneapolis, 2017). Other studies, however, confirm that the marginal benefits of higher capital are positive, but decline monotonically (Almenberg et al., 2017, Cline, 2010, Fender and Lewrick, 2016). Research by the Basel Committee confirms this view: according to BCBS (2019b), the net marginal benefits of adding more capital are positive, but approach zero once banks meet a capital ratio of about twelve percent.

It should be noticed that there is only so much than bank capital can do. For example, there is no compelling evidence that confirms bank capital requirements can help prevent financial crises (Jordà et al., 2017, BCBS, 2019b). Dautoviç (2019) finds that higher capital may induce risk taking. Lastly, Arnould et al. (2020) document a convex relation between capital ratios and funding costs, with senior bond rates reaching a minimum around CET1 ratios of about 11 percent: higher capital ratios have downsides as well.

While the higher, post-GFC, capital ratios undoubtedly have important benefits, the transition to these higher capital requirements is not necessarily unproblematic. Gropp et al. (2016) find that European banks, confronted with a sudden increase in capital requirements reduced lending. This instead of raising equity levels. De Marco and Wieladek (2016) shows that SME lending is sensitive to capital requirements increases. De Jonghe et al. (2019) and Jensen (2015) confirm these results for bank-specific capital requirements. Bahaj et al. (2018) complement these studies and show that lending is likely to be more sensitive to changes in capital requirements in times of weak credit growth. Confirming Gropp et al. and others, Kashyap et al. (2010) note that reduced lending by banks leads to a migration of business to shadow banks.

Regarding banks' funding decisions in response to higher capital requirements, Lubberink and Renders (2018) and Vallée (2019) show that during the lead-up to the implementation of Basel III, poorly capitalised banks engaged in Liability Management Exercises to bolster their Core Tier 1 ratios, which was at the expense of the banks' liquidity and Total Capital ratios and led to wealth transfers from owner to debt-holders.

Surprisingly little has been written about discretionary bank buffers. For example, Barth et al. (2005) mention these buffers in passing, see their figures 3.6 and 3.8. Mathur (2019) examines bank buffers in the context of policy uncertainty and finds that banks facing more policy uncertainty 
have larger discretionary buffers. However, Mathur examines only UK banks. EBA's Melis and Weissenberg (2019) examine a larger sample: they cover European banks. Their data, however, is largely restricted to the third quarter of 2017. Nevertheless, their conclusions are relevant for my study: Melis and Weissenberg examine the link between discretionary bank buffers and risk taking. Unlike me, they do not find evidence to support the existence of such a link. Neither do they empirically link discretionary bank buffers to stress testing, a link that has become more relevant for European banks since June 2016, see Section 2.2 below.

The sparse research on discretionary bank buffers then prompts the question whether these buffers are relevant. For example, can the results of Melis and Weissenberg and Mathur be generalised for a longer time period and for other countries? Can these buffers be associated with characteristics such as bank risk? Do banks increase these buffers to mitigate risks?

Using unique, hand-collected data of the composition of bank capital from the 99 largest European banks over 2013-2019, I document a negative association between discretionary capital buffers and non-discretionary, or required, bank capital. This negative association could just mean that an increase of non-discretionary capital sufficiently captures risks that were not captured without the increase. The increase in non-discretionary capital would thus offset the decline of discretionary capital, without making a bank more or less risky. To assess if that is the case, I examine the association between discretionary bank buffers and bank risk. My results then show that diminished discretionary bank capital is associated with elevated risk: yields on contingent convertible capital instruments (CoCos, or Additional Tier 1 capital) increase with declining levels of discretionary capital. Densities (the ratio of risk-weighted assets to total assets) increase as well, while Z-scores decrease. Evidence from the March 2020 COVID-19 price crash shows that the price drop is significantly stronger for banks with low discretionary capital.

These results hold, even after controlling for non-discretionary, required bank capital.

An examination of banks' responses to EBA stress test results shows that European banks subjected to the SSM which perform well (poorly) in these tests increase (decrease) discretionary bank capital, whereas European regulators arguably expect poorly performing banks to augment capital, not deplete it. 


\subsection{Regulatory Capital in Europe}

This section explains how various capital buffers are positioned in the overall EU capital framework. Figure 1 shows an overview of the European bank capital framework, that is, for banks subjected to the Capital Requirements Regulation (CRR, EC, 2013b) and the Capital Requirements Directive (CRD, EC, 2013a). The left bar shows regulatory values under the EU's implementation of Basel III, the CRR and CRD. The bar at the right shows actual average values for 2018 .

[Figure 1 about here]

The primary Basel III capital requirements are 4.5 percent of Common Equity Tier 1 (CET1) over Risk-weighted assets (RWA) plus 1.5 percent Additional Tier 1 and 2 percent Tier 2 capital. These are Pillar 1 capital requirements, which should cover Credit Risk, Market Risk, and Operational Risk. On top of these Pillar 1 requirements are three buffer requirements, denoted with an asterisk: a 2.5 percent capital conservation buffer, a counter-cyclical buffer that is limited to 2.5 percent of RWA and a 1 to 5 percent capital surcharge for systematically important banks (SIB buffers). I use shades of green to highlight requirements that should be met with common equity capital. $^{1,2}$

The total CRR common equity requirement can thus stack up to 14.5 percent. Total Capital requirements, ignoring Pillar 2, can stack up to 18 percent because of the inclusion of subordinated debt: Additional Tier 1, or CoCos, and Tier 2 for 1.5 and 2 percent of Risk-weighted assets respectively.

\subsubsection{Pillar 2 Guidance and Pillar 2 Required}

On top of the Pillar 1 requirements, European banks should also satisfy Pillar 2 requirements. These cover risks other than those covered by Pillar 1, for example reputational risk and concentration risk.

\footnotetext{
${ }^{1}$ Under CRR (EC, 2013b), Pillar 2R can be met with 75 percent common equity. However, my research focuses on capital of the highest quality only, i.e. CET1.

${ }^{2}$ CRR-II Article 104a 4 relaxes the full equity requirement for the combined buffer requirement, which shall be met by at least 75 percent common equity. CRR-II will not affect my results, as it enters into force in 2019.
} 
Pillar 2 requirements are generally set in the Supervisory Review and Evaluation Process (ECB, 2018). This process, also known as SREP, is a dialog between the supervisor and the bank, where both agree on a capital level that covers all relevant risks. The SREP capital requirement is bankspecific. Figure 1 and Table ?? show that SREP capital typically exceeds 2 percent of Riskweighted assets.

Traditionally, Pillar 2 requirements are unobservable. However, in December 2015, the European Banking Authority published an opinion that required banks to disclose the SREP results, including the composition of any additional capital requirements (EBA, 2015). This was novel: Pillar 2 and SREP results are traditionally kept out of the public eye.

Banks responded positively to the EBA opinion: about 65 percent of the sample banks disclosed SREP requirements in 2015. Figure ?? Panel 3 and Table ?? show that disclosed SREP requirements for 2015 were the highest of all years.

The initiative to require banks to publish the SREP results, however, was short-lived. In February 2016, investors grew nervous about Deutsche Bank. Aware of its $€ 6.7 \mathrm{bn}$ loss for fiscal year 2015 and the EBA opinion of that year's December, they worried about Deutsche Bank's ability to pay coupons on Additional Tier 1 instruments (Shotter, 2016). On February 8, 2016, the bank, prompted by market developments, announced that it was able to pay AT1 coupons of approximately $€ 0.35$ billion. Unfortunately, this announcement rattled the markets. The day after, Deutsche Bank's AT1 securities (CoCos) traded at 70-75 cents on the dollar, down from 93 cents at the start of the year (Deutsche Bank, 2016, Cotterill, 2016).

Shortly after the events of February 2016, the European Commission decided to split Pillar 2 capital into two elements: a guidance part (P2G) and a requirements part, or P2R (Glover, 2016). Where Pillar 1 and P2R are "hard" requirements that banks should always meet, the Pillar 2 Guidance part (P2G) is a "soft" buffer. A bank that dips into this buffer will prompt the supervisor's attention, but actions will be focused on increasing capital in a discrete and bespoke way. Investors and depositors will not necessarily know. 


\subsubsection{The Maximum Distributable Amount}

Banks that do not meet the combined buffer requirements, the 4.5 percent CET1 capital requirement, and P2R will not be allowed make distributions such as dividends, bonuses, and coupons on some debt instruments. These banks are then required to satisfy rules governing the 'Maximum Distributable Amount' or MDA (EC, 2013a, Article 142). Consequently, banks face a hard capital requirement being the sum of the combined buffer requirements, the 4.5 percent CET1 base capital requirement, and $\mathrm{P} 2 \mathrm{R}$.

\subsubsection{Pillar 2 and EBA stress testing}

In June 2016, European bank regulators decided to exempt the Pillar 2 Guidance (P2G) from EBA stress test results and the MDA calculations. According to Danièlle Nouy, then Chair of the Supervisory Board at the ECB: "Only the requirements are MDA-relevant, not the guidance, because there is no automaticity with transforming the guidance into a requirement. ... The outcomes of the stress test are expected to be in the guidance. They will not be MDA-relevant." (Henry, 2016). EBA guidelines on SREP and stress testing confirm that competent authorities should determine and set P2G based on the outcomes of the adverse scenario of the relevant supervisory stress tests (EBA, 2018, 2020).

\subsubsection{The SREP letter and the AT1 \& Tier 2 shortfall}

After the publication of EBA (2015), banks started reporting on Pillar 2 and SREP requirements more systematically. Unicredit's annual report of 2015, for example, explicitly mentions the requirements: "the European Central Bank (ECB) set the following capital requirements for UniCredit on a consolidated basis: 9.5\% CET1 (transitional)." Criteria Caixa (Spain) mentions in its 2015 annual report: "The European Central Bank (ECB) issued Criteria the minimum regulatory capital requirements after analysing the results of the supervisory review and evaluation process (SREP), which requires maintaining a regulatory CET1 ratio of 9.25\%."

By fiscal 2018, except for seven, all banks report Pillar 2 or SREP requirements, often referring to the SREP letter received from the ECB. By 2019, many banks disclose the ECB SREP letter requirements in press releases. 
From 2018 on, banks cannot count as CET1 capital any shortfalls of Additional Tier 1 and Tier 2 capital (ECB, 2018). This shortfall affects the discretionary buffer by 1.14 percent.

\subsubsection{Pillar 2 disclosure requirements}

Regarding the disclosure of Pillar 2 or SREP requirements, banks are free to disclose them in full, be it P2R or P2G. A reason to disclose these requirements, including P2G requirements, is that the market conduct regulator may regard this information as price-sensitive, and hence wants banks to disclose. Nine sample banks do report P2G data: OP Financial group (Finland), Banca Monte dei Paschi, Banca Carige, and Iccrea Banca (Italy), Raiffeisen Bank International, BAWAG (Austria) and Belgian banks KBC, Belfius, and Dexia.

\subsection{Research questions}

The sections above prompt various questions on discretionary bank capital buffers. These are i) whether these capital buffers are associated with bank characteristics, given that Melis and Weissenberg (2019) find no relation based on their sample, $i$ ) whether these capital buffers are relevant. For example, Dautoviç (2019) shows a link between capital levels and bank risk, iii) whether banks use stress test outcomes to build discretionary bank capital buffers, this to mitigate risks going forward.

I focus on bank risk and risk mitigation. The reason is that SREP capital requirements should cover risks not covered by Pillar 1. If SREP and Pillar 1 capital effectively cover all bank risks, then banks' discretionary buffers should not be associated with risk. This then prompts the question if discretionary bank buffers are associated with bank risk.

\section{Data and research design}

\subsection{Pillar 2 and SREP data}

This paper exploits Pillar 2 data that banks started reporting more systematically since the publication of EBA (2015). The research design relies on unique, hand-collected, SREP and Pillar 2 data from 99 individual European banks.

The sample banks all participated at least once in EBA transparency exercises or EBA stress tests over the years 2012 to 2018. In a first pass, I collected data from the largest banks based 
on Risk Weighted Assets for the year 2017. As some countries host relatively small banks, I also include data from banks in Bulgaria, Estonia, Latvia, Malta, Romania, and Slovenia. To mitigate survivor bias, the sample also includes data from two failed banks (Banco Popular, ABLV Bank). I excluded subsidiaries of banks to prevent double counting of assets and liabilities. More importantly, bank supervision focuses on consolidated data, which consequently determines the prudential information I use. My sample also excludes banks with five observations or less and car-financing companies such as Renault Crédit International. I coded Nordea as a Swedish bank, as this bank only moved headquarters from Sweden to Finland in 2018, near the end of the sample period. Data for Portugese bank Novo Banco includes data from its predecessor BES.

Figure ?? shows (next to total capital ratios), in brackets the number of banks and observations for each country.

[Figure ?? about here.]

I obtained data on the composition of capital, including Pillar 2 and SREP data from annual and semi-annual reports, Pillar 3 disclosures, registration reports (France), Offenlegungsberichte (Germany), investor presentations, and press releases. Over the sample period, banks improved their disclosures of capital requirements significantly. Until 2015, there is large variation in the way banks report capital requirements. About one in five banks report only the basic capital amounts and ratios, often in a separate section on capital adequacy in their Pillar 3 report or annual report. However, about 60 percent of the banks also report expectations or targets regarding capital that go beyond the bare minimum requirements. Many banks report expectations about capital ratios derived from stress tests, in particular after the 2014 stress test. These expectations and targets are likely agreed with the supervisor.

During the early sample years, some banks prospectively refer to the introduction of Basel III and incorporate its expected requirements into their capital disclosures. For example, Unicredit, in its 2013 (!) annual report mentions:

"[the] target Core Tier 1 ratio is $9 \%$, in line with the expectations following the introduction of the new regulatory framework. Basel 3 rules have introduced a new 
target of $7 \%$ for Core Tier 1 which is equal to the sum of the new minimum and the conservation buffer. The additional $2 \%$ arises from the Group being designated as Systemically Important Financial Institution (SIFI) and the possible introduction by national banking regulators of additional buffers."

Permanent TSB Group refers to a regulatory capital minimum despite the absence of a clear legal base for such a minimum requirement:

"The Group's core tier 1 capital ratio at 31 December 2013 is $13.6 \%$ (31 December 2012: $18.0 \%$. This compares to a regulatory capital minimum of $10.5 \%$."

Some national supervisors set minimum standards for Core Tier 1 ahead of the entry into force of Basel III: Greece, Spain, and Portugal, in 2013, mention a minimum Core Tier 1 ratio requirement of 9 percent.

For this paper, given that these expectations exceed legal requirements of the CRD, are almost certainly published with the supervisor's approval (tacit or explicit), and publicly disclosed as requirements, I coded these as SREP requirements. Discretionary buffers ('headroom', or own buffers) are then defined as reported CET1 capital minus the summed requirements, including SREP requirements.

My sample includes banks subjected to the SSM as well as banks from countries not subject to the SSM: Bulgaria, Denmark, Hungary, Norway, Poland, Romania, Sweden, and the United Kingdom. Banks in these countries do not report P2G separately. UK banks, however, report Pillar 2A or P2A requirements, which are akin to P2R. In addition to the hand-collected data, I use data from the EBA transparency exercises and stress tests to measure capital under adverse stress scenarios and to obtain information on non-performing loans and credit growth. I use Refinitiv's Eikon and Datastream for market data on equity and Additional Tier 1 capital instruments.

\subsection{Analysis of Discretionary Buffers}

My identification strategy follows three steps. First, I examine the relation between discretionary buffers, other buffers, and bank characteristics. Based on the results of this analysis, I examine if any of these characteristics are associated with bank risk. Lastly, as an extension of the second 
step, I examine if banks attempt to mitigate risks by strengthening discretionary buffers after an adverse stress test result, which is not only a sensible undertaking, it is also required (EBA, 2018).

\subsubsection{Discretionary buffers and bank characteristics}

My primary variable of interest is the bank's discretionary buffer: DiscBuffer. This buffer is the difference between the reported Core Tier 1 or Common Equity Tier 1 ratio and the sum of all CET1 or CT1 requirements, including disclosed additional and SREP requirements, as well as disclosed P2R (and P2A for British banks). I exclude P2G capital as well as discretionary capital requirements for capital other than CET1 or CT1. I estimate the following model:

$$
\text { DiscBuffer }_{i, t}=\beta_{0}+\beta_{1} \times \text { SREP }_{i, t}+\beta_{2} \times \text { CombBuffer }_{i, t}+\text { Control }_{i, t}+\varepsilon_{i, t}
$$

where I define DiscBuffer as the difference between reported capital and the sum of the requirements:

$$
\begin{aligned}
& \text { DiscBuffer }_{t \leq 2013}=C T 1_{\text {reported }}-\left(S R E P+S I B+C C y B+\text { ConsBuffer }+C T 1_{B I I}\right) \\
& \text { DiscBuffer }_{t \geq 2014}=C E T 1_{\text {reported }}-\left(S R E P+S I B+C C y B+\text { ConsBuffer }+C E T 1_{\text {BIII }}\right)
\end{aligned}
$$

Equation (2) reflects the change of the definition of capital of the highest quality from "Core Tier 1" under Basel II into "Common Equity Tier 1" under Basel III. For years after 2017, DiscBuffer ${ }_{t \geq 2014}$ is net of the AT1, Tier 2 shortfall.

SREP is the requirement agreed with the supervisor as an outcome of the Supervisory Review and Evaluation Process. This variable includes P2R, P2A, and similar additional bank-specific requirements obtained from banks' disclosures. The combined buffer requirement is defined as: CombBuffer $=S I B+C C y B+$ ConsBuffer $+C(E) T 1_{B I I \mid I I I}$, where $S I B$ is any buffer for systemically importance (globally or domestically), $C C y B$ is the countercyclical capital buffer designed to help counter pro-cyclicality in the financial system. ConsBuffer is the capital conservation buffer, designed to ensure that banks build up capital buffers outside periods of stress which can be drawn down as losses are incurred. The last term is the base Basel CT1 or CET1 capital requirement.

Equation (1) uses the following controls: Density, the ratio of RWAs over Total Assets, which is a measure of risk (Bruno et al., 2015, Melis and Weissenberg, 2019); Size, the log of Total As- 
sets; Z-score, defined by Cihák and Hesse (2007), Ayadi et al. (2017) as $\frac{L R+R O A}{\sigma(R O A)}$, where $L R$ is the leverage ratio and ROA the return on assets; Profitability, the return on equity (ROE, in percent); $S S M$, a binary value set to one for banks that are subjected to the Single Supervisory Mechanism; Credit Growth defined as the relative change in credit exposure values over one year. The regression models rely on $p$-values that account for two-dimensional within-cluster correlation.

I rely on the transitional CET1 ratios, which banks should report under the CRR (EC, 2013b). Some banks report "fully phased in" capital ratios. These are pro-forma ratios assuming fully implemented Basel III rules. However, only a subset of the sample banks report these, thus making like-for-like comparisons difficult.

Regarding the expected coefficients on controls, based on Melis and Weissenberg (2019), I expect negative coefficients on Density. Larger banks are known to report lower capital ratios, the associated coefficient on Size value thus should be negative (EBA, 2019a, BCBS, 2019a). Based on Jensen (2015), Gropp et al. (2016), De Marco and Wieladek (2016), De Jonghe et al. (2019), I expect negative coefficients on Credit Growth.

Note that Density could be an endogenous variable. To explore the relation between this variable and discretionary bank buffers, I separately run an instrumental variables regression. This regression uses the geographical latitude of a bank's headquarters as an instrument for Density.

\subsubsection{Discretionary buffers and measures of risk}

Using a multivariate regression model, I examine the following measures of bank risk: Zscores, yields on subordinated hybrid capital instruments (Additional Tier 1, or AT1), density, and the price drop during the first weeks of March 2020 due to the COVID-19 price crash:

$$
\sigma_{i, t}=\beta_{0}+\beta_{1} \times \text { DiscBuffer }_{i, t}+\beta_{2} \times \text { SREP }_{i, t}+\beta_{3} \times \text { CombBuffer }_{i, t}+\text { Controls }_{i, t}+\varepsilon_{i, t}
$$

where $\sigma_{i, t}$ is either, Z-score, Yields on AT1, Density, or the COVID-19 price crash. Controls are Overall Requirement, or the Combined buffer requirement plus the SREP requirement, Size, NPE ratios, Profitability, and Credit Growth, all as previously defined. The regression models rely on $p$-values that account for two-dimensional within-cluster correlation. 
If higher discretionary buffers decrease bank risk, I expect coefficients values on discretionary buffers to be positive for Z-scores and share prices, and negative for yields and densities.

\subsubsection{Discretionary buffers and stress test results}

For the responses to stress test results, I rely on EBA stress test data to estimate:

$$
\begin{aligned}
\text { DiscBuffer }= & \beta_{0}+\beta_{1} \cdot \text { CET1 } 1^{\text {Stress }}+\beta_{2} \cdot S S M+\beta_{3} \cdot C E T 1^{\text {Stress }} \times S S M+\beta_{4} \cdot \text { SREP }+ \\
& \beta_{5} \cdot \text { CombBuffer' }+ \text { Controls }+\varepsilon
\end{aligned}
$$

where DiscBuffer is the discretionary buffer.

I run this regression for all years from 2014 to 2018, even though the EBA runs stress tests in even years only $(2014,2016$, and 2018). The reason to include all years from 2014 to 2018 is that banks can respond to the stress test results in the year of the test and the year after. There is ample time to respond. For example, the EBA announced the final methodology for the 2018 EU-wide stress test on 17 November 2017. The results of the 2018 test were published almost a year later (2 November 2018). The announcement of the 2020 EU-wide stress test methodology was on 7 November 2019. Likewise, I use the stressed CET1 ratio $\left(C E T 1^{\text {Stress }}\right)$ as a regressor for the year of a stress test and the next, given that this ratio is the two-years out CET1 ratio from the adverse test scenario.

Equation (4) interacts $C E T 1^{\text {Stress }}$ with $\operatorname{SSM}\left(\beta_{3}\right)$ and it uses the following controls: SREP, the requirement agreed with the supervisor as an outcome of the Supervisory Review and Evaluation Process, CombBuffer' is the Combined Buffer requirement minus the Stressed CET1, this to avoid double counting, Density, Size, Profitability, NPE ratio, and Credit Growth, all as previously defined.

The EBA guidelines on common procedures for the SREP and stress testing require that the outcomes of the adverse scenario of the stress tests determine and set Pillar 2 Guidance capital, or P2G (EBA, 2018). In the absence of the exact P2G data, I rely on banks' discretionary capital buffers as a proxy for $\mathrm{P} 2 \mathrm{G}$. This is not an unreasonable assumption. Assuming that banks wish 
to retain a constant management (or own) buffer, the stress test results should affect the space not occupied by the banks' own management buffer.

The EBA guidelines create the expectation of a negative relation between the discretionary capital buffers and $C E T 1^{\text {Stress: }}$ a poor stress test result should prompt banks and their supervisors to increase discretionary capital buffers.

\subsection{Descriptive Statistics}

Table ?? and Figures ?? and ?? show that, since the entry into force of Basel III, reported CET1 ratios have increased significantly. By 2018 these clearly exceed minimum requirements. Figure ?? shows that Total Capital ratios range from 14.7 (PT) to over 22.9 percent (NL), with banks in the south of Europe reporting lower than average ratios. ${ }^{3}$

[Table ?? and Figure ?? about here.]

The table shows that the average discretionary buffer is 5.59 percent, significantly higher than the SREP requirement. Figure ??, however, shows that the distribution and the evolution of both buffers are distinct. Panel 1 of Figure ?? shows that the SREP requirements have decreased since 2016, whereas the discretionary buffer appears to be relatively constant, with a drop in 2018 because of the AT1 and Tier 2 shortfall deduction. ${ }^{4}$ Panel 3 of Figure ?? shows a clear downward shift of the SREP requirements since 2016. This drop in SREP requirements is about 1.5 percent, and significant ( $p$-value of 0.00 ).

Stressed CET1 ratios in Table ?? are the two-years out CET1 ratios reported under the adverse scenario of the EBA stress test. The stressed ratios are well below required or reported CET1 ratios, with a minimum of -6.42 achieved by Eurobank Ergasias in the 2014 stress test.

\footnotetext{
${ }^{3}$ The average capital ratio of the countries shown in Figure ?? is slightly lower than the average reported in Figure 1. This is because the latter shows the average of bank-year observations, whereas the former shows the ratios calculated as the sum of total bank capital for all countries divided by the sum of total Risk-weighted assets, also for all countries, which returns size-adjusted averages. Given that smaller banks are generally better capitalized, the size-adjusted average Total Capital ratio will be lower than the equally-weighted ratio.

${ }^{4}$ Panel 1 of Figure ?? also reports the 2019 SREP and aggregate requirements as banks disclosed these via press releases, investor presentations, or in their (quarterly, semi) annual reports at the end of 2018 and the start of 2019.
} 
Panel 2 of Figure ?? shows the variation in discretionary buffers, SREP requirements, and the combined buffer requirements for the sample countries. It is worth pointing out that Swedish (SE) and Norwegian (NO) capital requirements are relatively high, but the discretionary buffers are small. This is likely because the prudential supervisors of both countries exclude Pillar 2 requirements from the MDA calculation. Unlike most other EU banks, banks in Sweden and Norway that not meet expectations of the supervisory review process are thus treated relatively leniently.

The overall CET1 capital requirements reported in Table ?? vary between 4 percent (2013) to well over 21 percent (Swedbank 2016 and 2017). The combined buffer requirement reflects the evolution of the primary Pillar 1 requirements, in particular by the capital conservation buffer. The maximum value of 13.7 percent originates from DNB bank Group.

Table ?? also shows that bank profitability is weak, with ROE ratios at an average of 3.24 percent, though admittedly these ratios have improved gradually over time. Z-scores have commensurately improved, while NPE ratios have declined marginally. Market metrics show that PE-ratios have declined since 2016 and that three out of four EU banks report market values below book equity, thus confirming the vulnerable state of European banks.

Table 2 and Figure ?? present Pearson (above diagonal) and Spearman correlations (below diagonal) for the main variables. Correlation coefficients worth pointing out are those between densities, NPE-ratios and Yields on AT1 capital instruments. This indicates that densities act as a proxy for risk.

[Table 2 and Figure ?? about here.]

Reported CET1 ratios are associated with discretionary buffers, combined buffers, profitability, Z-scores, and Market to Book ratios. These correlations confirm the literature on bank capital: Reported CET1 ratios are associated with more resilient and better-performing banks.

Note that SSM banks show negative correlations for reported CET1 ratios, SREP requirements, combined buffer requirements, and various metrics of performance. This appears to indicate that EU banks are less resilient than non-SSM banks. 
Lastly, note that the latitude of banks' headquarters correlates with measures of resilience (CET1, the combined buffer, profitability, Market to Book), not strongly with discretionary buffers, and okay-ish with densities. For an instrumental variables regression examining the relation between this variable and discretionary bank buffers, Latitude would thus work as an instrument for Density.

\section{Results}

\subsection{Discretionary buffers and other buffers}

Table 3 presents the results from regression equation (1). The dependent variable is the discretionary buffer and the main regressors are the SREP requirement and the combined buffer requirement. I control for density, size, Z-score, profitability, whether the bank is subjected to the SSM, and credit growth.

\section{[Table 3 about here.]}

Model I presents pooled OLS results, whereas models II, III, and V control for fixed and time effects. Model IV acknowledges the potential causality between densities and discretionary buffers: It could well be that Density is an endogenous variable and that this variable and discretionary buffers are determined by an unobservable variable, e.g. a bank's risk appetite. To examine this potential endogeneity issue, I use the latitute of a bank's headquarters as an instrument for density (Barth et al., 2005, Chapter 5). Table 2 shows that densities and latitude are somewhat correlated and that latitude is not correlated with discretionary buffers.

Model V uses logs of buffer ratios $\times$ Risk Weighted Assets to assess whether equation (1) is affected by spurious correlation.

The results of Table 3 confirm that the discretionary buffer is negatively associated with SREP requirements. The coefficient values on $S R E P$ are about -0.85 for models I to IV and -0.54 for Model V. Moreover, all models indicate this negative association is significant. This is also the case for the combined buffer requirement. The coefficients on the SREP requirement are negative while controlling for the main capital requirements (i.e. the combined buffer requirement). SREP requirements thus almost completely substitute for discretionary buffers. 
Regarding the other control variables, discretionary buffers are negatively associated with densities, size, and credit growth. They are positively associated with Z-scores.

The negative association between discretionary buffers and densities is significant in all models, a result that may indicate that low discretionary buffers are associated with elevated risk. The negative coefficient on size is negative as expected, as larger banks generally report lower capital ratios. The negative coefficient on credit growth conforms results from studies that show higher capital ratios affect lending (Jensen, 2015, Gropp et al., 2016, De Marco and Wieladek, 2016, De Jonghe et al., 2019).

Model IV shows the results of a two-stage instrumental variables approach where latitude is an instrument for endogenous variable Density. The results of the IV-regression show a negative association between Density and discretionary buffers. The IV coefficient on Density is about twice as high as the associated OLS coefficient, while the other regressors are similar to those of Models I to III. The bottom row of Table 3 shows the Durbin Score and the Wu-Hausman statistics. Both reject the null of the variables being exogenous. This justifies the use an instrumental variables approach. Latitute is also a strong instrument: the $F$-statistic for joint significance of instruments is 42.6., well over the rule of thumb value of 10 .

The coefficients of Model V, which uses logged un-scaled data for the main coefficients, are similar to the coefficients of the other models. ${ }^{5}$ From that I infer that the other models do not suffer from spurious correlation.

It should also be noticed that these results document a consistent association between discretionary bank buffers and bank characteristics, while the EBA, based on the analysis of Melis and Weissenberg, claims it cannot make statements about such an association.

From these results I infer that banks' discretionary buffers appear to compensate for higher nondiscretionary capital requirements. However, this negative association between required capital and discretionary buffers could be mechanical. As shown by the two bottom panels of Figure ??, the former may change whereas the latter may be fairly constant. More importantly, the results in Table 3 show that lower discretionary buffers are associated with measures of bank risk, e.g.

\footnotetext{
${ }^{5}$ In Model V, Density is the log of RWAs.
} 
Z-scores and densities. These results warrant further testing as they could either indicate that riskier banks choose to lower their discretionary buffers, or that banks with lower buffers choose to augment their risk appetite to increase profitability.

\subsection{Discretionary buffers and measures of risk}

Table 4 and Table 5 examine the relation between measures of banks risk and discretionary buffers. The measures are Z-scores, Yields on Additional Tier 1 capital instruments, densities, and the price drop during the first weeks of March 2020 due to the COVID-19 price crash.

\section{[Table 4 and Table 5 about here.]}

Panel A of Table 4 reveals that discretionary buffers are positively related to Z-scores, which confirms that more resilient banks have higher discretionary buffers. Similarly, banks that meet a higher combined buffer requirement show higher Z-scores, as do banks with higher SREP requirements. Regarding the other control variables, larger banks have lower Z-scores, perhaps because they may rely on implicit government guarantees, despite recent evidence to the contrary Berndt et al. (2019). The coefficients on NPE ratios and Credit growth are inconclusive.

Panel B shows that AT1 yields are negatively associated with discretionary buffers. AT1 yields are also negatively associated with other capital buffers: the coefficient on the overall capital requirement is negative and significant ( $p$-value of 0.10 ), albeit that significance weakens after disaggregating the overall capital requirement into the SREP requirement and the combined buffer requirement. Larger banks report lower yields, a result in line with the results of Panel A. As expected, the coefficients on NPE ratios are positive.

Panel $\mathrm{C}$ shows that densities are lower for banks with higher discretionary buffers, a result that confirms the findings reported in Section 4.1. The coefficients on NPE ratios are positive, indicating that banks with poor asset quality have higher densities.

Table 5 examines the effects of a drop in bank share prices during the days from February 19 to March 13, 2020. In this period share prices dropped significantly, about 30\%. It is expected that such a share price crash will have a disproportionate effect on banks with low discretionary buffers. 
The analysis of the COVID-19 crash regresses the share price drop $(x-1)$ on Discretionary buffers, CET1 capital requirements, and previously defined controls. In the absence of up to date information, the regressors originate from 2018. This may bias my results, however, many of the regressors are sticky over time.

The results shown in Table 5 confirm my expectations, banks with low discretionary buffers and low capital buffers are associated with a more severe price shock. The coefficients on Discretionary buffers are negative and significant. Also significant are the coefficients on SSM and NPE ratios. These results indicate that banks subjected to the SSM and banks with poor asset quality are particularly affected by the COVID-19 crash.

\subsection{Bank's responses to stress test results}

Table 6 shows the responses of banks to the EBA stress tests of 2014, 2016, and 2018. The sample uses data from the year of the test and the year after. I assume that banks which conform with the EBA guidelines on SREP and stress testing (EBA, 2018) have an opportunity to respond to stress tests results during the year of the test and the year after.

[Table 6 about here.]

The first column pair of Table 6 presents results from the full stress test sample. The next two column pairs examine sub-samples for the years before and since 2016, because the distinction between P2G and P2R was introduced in that year for SSM banks.

Based on the EBA guidelines on SREP and stress testing (EBA, 2018), I expect the coefficient on Stressed CET1 to be negative: banks that perform poorly in the stress test should increase discretionary bank buffers.

The results show negative and significant coefficients on Stressed CET1 ratios, indicating that banks augment discretionary buffers after a stress test. However, this is different for SSM banks: the interaction between stressed CET1 and SSM is positive and significant, specifically for the years since 2016. SSM banks that perform well (poorly) in the stress test report higher (lower) discretionary bank capital buffers. As such, these results indicate that SSM banks fail to strengthen 
their discretionary bank capital buffer after a poor stress test outcome, which does not dovetail with supervisory guidelines.

Coefficients on the SREP requirements and combined buffer requirements are generally negative, consisten with prior results.

It is noteworthy that the coefficient on SSM is negative, in particular for sample years since 2016. Moreover, the coefficent on NPEs is positive, which indicates that banks with higher NPEs increase their buffers. Many of the controls confirm results reported in the previous subsections, eg. negative coefficients on size, densities, credit growth, etc.

Table 7 shows a variation of Table 6 using a difference in difference approach. Note that the first column pair of the table shows regression results using only the countries that participate in the stress test, whereas the second column pair includes all banks. It uses an indicator $\left(D^{N S}\right)$ to differentiate between banks that do not participate in the EBA stress tests. In addition, Model II, CET $1^{\text {Stress }}$ has a value of zero for observations from banks not participating in the stress test. These 'zero' observations thus complement $D^{N S}$, which is set to one for these (non-participating) banks.

[Table 7 about here.]

The results confirm results of the previous table, in particular the coefficients on SSM $\times$ Stressed $C E T 1 \times Y 2016$ and $S S M \times$ Stressed CET $1 \times Y 2018$. Both are positive, with the coefficients clearly significant for 2018 .

The coefficient on SSM is negative, in particular for the sample dominated by stressed banks $(-2.51, p=0.09)$. The coefficient on stressed CET1 is negative and just significant $(-0.30, p=$ $0.07,-0.42, p=0.04)$, indicating that banks with a poor stress test performance do augment their discretionary buffers. However, the interaction coefficient on SSM $\times$ Stressed CET1, offsets the negative coefficient on stressed CET1. Coefficients values for the year indicators 2016 and 2018 are positive and indicate an increase in management buffers over time, but again, these coefficients are offset by coefficients on the SSM indicator variables. 
In all, the results of this section indicate that European banks, specifically those that are subjected to the SSM, struggle to build discretionary buffers after a stress test, despite supervisory guidelines to do so. The struggle to build buffers is more pronounced for the later sample years, which raises questions about the commitment from both banks and supervisors to rely on P2G buffers to augment bank capital.

\section{Additional tests}

Regarding robustness tests, I reran the regressions using various specifications. In all, the inferences remain the same. Regarding banks' responses to the EBA stress tests, there is a case for examining banks' responses to the projected drawdown of CET 1 ratios, e.g. from contemporary $C E T 1$ ratios to the two-years out CET 1 ratio from the adverse test scenario. Untabulated results from regressions of discretionary buffers on the relative CET 1 ratio drawdown indicate that the levels of the stressed CET1 values are more important than drawdowns. This result makes sense, given that the best capitalized banks will still be well-capitalized after a severe stress test.

\section{Conclusion}

This paper examines the association between discretionary bank capital buffers, capital requirements, and risk for European banks. The discretionary buffers are banks' own buffers, or headroom, being the difference between reported and required capital.

I exploit detailed information of capital requirements that banks started to disclose after the release of an European Banking Authority opinion in 2015. Using hand-collected SREP and Pillar 2 data from the 99 largest European banks over the years 2013-2019, I show that lower discretionary buffers are associated with increased bank risk: yields on contingent convertible capital instruments (CoCos, or Additional Tier 1 capital) increase with declining levels of discretionary capital. Densities (the ratio of risk-weighted assets to total assets) increase as well, while Z-scores decrease. Evidence from the March 2020 COVID-19 price crash shows that the price drop is significantly stronger for banks with low discretionary capital. These results hold, even after controlling for non-discretionary, required bank capital: Headroom matters.

Regarding the role of discretionary buffers and risk mitigation, an additional examination of European banks' responses to stress tests reveals a positive association between discretionary buf- 
fers and stress test results, that is, for banks that are subjected to the Single Supervisory Mechanism (SSM). Poor stress test performance is associated with lower discretionary buffers in subsequent years, whereas supervisory guidance requires banks to use the stress test results to set, arguably strengthen, discretionary bank capital buffers. The positive association between discretionary buffers and stress test results is particularly strong for SSM banks during later sample years.

In all, my results show a negative association between discretionary buffers ('headroom') and risk and risk mitigation. Consequently, my paper shows further limits of the effectiveness of bank capital requirements.

Given the poor performance of European banks, my results may indicate that banks and supervisors acknowledge a trade-off between bank capital and profitability, thus confirming results from Goel et al. (2019).

Apart from the main findings, my data shows that European banks do disclose capital requirements. Many European banks did so before the publication of the EBA opinion that required them to do so (EBA, 2018). It is noticeable that nine out the 99 sample banks disclose Pillar 2 Guidance data. Mindful of Akerlof (1970), some of these banks are not necessarily the usual suspects: OP Financial group, Banca Monte dei Paschi, Banca Carige, Iccrea Banca, Raiffeisen Bank International, BAWAG, KBC, Belfius, and Dexia.

Lastly, it is noteworthy that the European Central Bank and the Bank of England, responding to the COVID crisis, recognised the importance of headroom and allowed banks to fully use capital buffers, including P2G (BoE, 2020, ECB, 2020). 


\section{References}

Acharya, V., R. Engle, and D. Pierret (2014). Testing macroprudential stress tests: The risk of regulatory risk weights. Journal of Monetary Economics 65, 36-53.

Admati, A. R., P. M. DeMarzo, M. F. Hellwig, and P. C. Pfleiderer (2016). Fallacies, irrelevant facts, and myths in the discussion of capital regulation: Why bank equity is not expensive. SSRN eLibrary (ID 1669704), 1-77.

Admati, A. R., P. M. DeMarzo, M. F. Hellwig, and P. C. Pfleiderer (2017). The leverage ratchet effect. The Journal of Finance 73(1), 145-198.

Akerlof, G. A. (1970). The market for 'lemons': Quality uncertainty and the market mechanism. Quarterly Journal of Economics 84, 488-500.

Almenberg, J., M. Andersson, D. Buncic, C. Cella, P. Giordani, A. Grodecka, K. Roszbach, and G. Söderberg (2017). Appropriate capital ratios in major Swedish banks - new perspectives. Number 170519. Stockholm: Sveriges Riksbank. https://www.riksbank.se/globalassets/media/ rapporter/staff-memo/engelska/2017/staff_memo_170519_eng.pdf.

Arnould, G., C. Pancaro, and D. Żochowski (2020, January). Bank funding costs and solvency. Frankfurt: ECB. https://www.ecb.europa.eu/pub/pdf/scpwps/ecb.wp2356 4a9ccc29af.en.pdf.

Ayadi, R., G. Ferri, and V. Pesic (2017, June). Regulatory Arbitrage in EU Banking: Do Business Models Matter? SSRN Electronic Journal (ID 2829027). https://ssrn.com/abstract=2829027.

Bahaj, S., J. Bridges, F. Malherbe, and C. O'Neill (2018, March). What Determines How Banks Respond to Changes in Capital Requirements? SSRN Electronic Journal (ID 2766374). https: $/ /$ ssrn.com/abstract $=2766374$.

Barth, J. R., G. Caprio, and R. Levine (2005). Rethinking bank regulation: Till angels govern. Cambridge University Press.

BCBS (2010). An assessment of the long-term economic impact of stronger capital and liquidity requirements. Basel: Bank for International Settlements. https://www.bis.org/publ/bcbs173. $p d f$.

BCBS (2018). Annual Economic Report 2018. Basel: Bank for International Settlements. https: //www.bis.org/publ/arpdf/ar2018e.pdf.

BCBS (2019a, October). Basel III Monitoring Report. Basel: Bank for International Settlements. https://www.bis.org/bcbs/publ/d477.pdf.

BCBS (2019b). The costs and benefits of bank capital - a review of the literature. Basel: Bank for International Settlements. https://www.bis.org/bcbs/publ/wp37.htm.

Berger, A. N. and C. H. Bouwman (2009, September). Bank liquidity creation. Review of Financial Studies 22(9), 3779-3837.

Berger, A. N. and C. H. Bouwman (2013). How does capital affect bank performance during financial crises? Journal of Financial Economics 109(1), 146-176.

Berndt, A., D. Duffie, and Y. Zhu (2019, March). The Decline of Too Big to Fail. Stanford: Australian National University. https://www.darrellduffie.com/uploads/pubs/ BerndtDuffieZhuTBTF.pdf.

BoE (2020). Bank of England measures to respond to the economic shock from Covid-19. https://www.bankofengland.co.uk/news/2020/march/ boe-measures-to-respond-to-the-economic-shock-from-covid-19. 
Bolton, P., X. Freixas, L. Gambacorta, and P. E. Mistrulli (2016, October). Relationship and Transaction Lending in a Crisis. Review of Financial Studies 29(10), 2643-2676. https: //academic.oup.com/rfs/article/29/10/2643/2223384.

Brainard, L. (2019). Financial stability. Basel: Bank for International Settlements. https://www. bis.org/review/r190925j.htm.

Brooke, M., O. Bush, R. Edwards, J. Ellis, B. Francis, R. Harimohan, K. Neiss, and C. Siegert (2015). Measuring the macroeconomic costs and benefits of higher UK bank capital requirements. Bank of England Financial Stability Paper 35(35), 1-55. http://www.bankofengland.co. $u k /$ financialstability/Documents/fpc/fspapers/fs_paper35.pdf .

Bruno, B., G. Nocera, and A. Resti (2015, June). The Credibility of European Bankss RiskWeighted Capital: Structural Differences or National Segmentations? SSRN Electronic Journal. https://ssrn.com/abstract=2613943.

Cihák, M. and H. Hesse (2007). Cooperative Banks and Financial Stability. IMF Working Papers. Cline, W. R. (2010). Preface: The Right Balance for Banks: Theory and Evidence on Optimal Capital Requirements. Washington: PIIE Press. https://www.piie.com/bookstore/ right-balance-banks-theory-and-evidence-optimal-capital-requirements.

Cotterill, J. (2016). The CoCo that popped. Financial Times. February 10, 2016.

Dautoviç, E. (2019, February). Has Regulatory Capital Made Banks Safer? Skin in the Game vs Moral Hazard. SSRN eLibrary (ID 3332501), 1-62. https://ssrn.com/abstract $=3332501$.

de Guindos, L. (2019). Welcome remarks, Vice-President of the ECB, at the ECB Forum on Banking Supervision. Frankfurt: European Central Bank. https://www.ecb.europa.eu/press/key/date/ 2019/html/ecb.sp191106 1910820033.en.html.

De Jonghe, O., H. Dewachter, and S. R. G. Ongena (2019, April). Bank Capital (Requirements) and Credit Supply: Evidence from Pillar 2 Decisions. SSRN Electronic Journal (ID 3356726). https://ssrn.com/abstract $=3356726$.

De Marco, F. and T. Wieladek (2016, November). The Real Effects of Capital Requirements and Monetary Policy: Evidence from the United Kingdom. SSRN Electronic Journal (ID 2869838). https://www.bankofengland.co.uk/working-paper/2015/ the-real-effects-of-capital-requirements-and-monetary-policy-evidence-from-the-uk.

DeAngelo, H. and R. M. Stulz (2013, June). Why high leverage is optimal for banks. Working Paper 19139, National Bureau of Economic Research.

Deutsche Bank (2016). Deutsche Bank publishes updated information about AT1 payment capacity - Newsroom.

Diamond, D. W. and R. G. Rajan (2001). Banks and liquidity. American Economic Review 91(2), 422-425.

EBA (2012). Results of the Basel III monitoring exercise based on data as of 31 December 2011. London: European Banking Authority. https://eba.europa.eu/documents/10180/16145/ EBA-BS-2012-xxx--Public-ISG-Report-Basel-III-Monitoring-.pdf.

EBA (2015, December). Opinion of the European Banking Authority on the interaction of Pillar 1, Pillar 2 and combined buffer requirements and restrictions on distributions. London: European Banking Authority.

EBA (2018, July). Guidelines on common procedures and methodologies for the supervisory review and evaluation process (SREP) and supervisory stress testing. London: European Banking Authority. https://eba.europa.eu/ eba-publishes-final-guidance-to-strengthen-the-pillar-2-framework. 
EBA (2019a). Basel III Monitoring Exercise - results Based on Data as of 31 December 2018. London: European Banking Authority. https://eba.europa.eu/sites/default/documents/files/Basel\% 20III\%20monitoring\%20exercise.pdf.

EBA (2019b, November). Risk Assessment Report. Paris: European Banking Authority. https: //eba.europa.eu/file/335155.

EBA (2020, January). EBA consults on the future of the EU-wide stress test framework European Banking Authority. London: European Banking Authority. https://eba.europa.eu/ eba-consults-future-eu-wide-stress-test-framework.

EC (2013a). Directive 2013/36/EU of the European Parliament and of the Council of 26 June 2013 on access to the activity of credit institutions and the prudential supervision of credit institutions and investment firms, amending Directive 2002/87/EC and repealing Directives 2006/48/EC and 2006/49/EC Text with EEA relevance. Brussels: European Commission.

EC (2013b). Regulation (EU) No 575/2013 of the European Parliament and of the Council of 26 June 2013 on prudential requirements for credit institutions and investment firms and amending Regulation (EU) No 648/2012. Brussels: European Commission.

ECB (2018). The Supervisory Review and Evaluation Process. Frankfurt: European Central Bank. https://www.bankingsupervision.europa.eu/banking/srep/srep_2018/html/index.en.html.

ECB (2020). ECB Banking Supervision provides temporary capital and operational relief in reaction to coronavirus. https://www.bankingsupervision.europa.eu/press/pr/date/2020/html/ssm. pr200312\{ \}43351ac3ac.en.html.

FED Minneapolis (2017, January). The Minneapolis Plan to End Too Big to Fail. Minneapolis: Federal Reserve Bank of Minneapolis. https://www. minneapolisfed.org/ /media/files/publications/studies/endingtbtf/the-minneapolis-plan/ the-minneapolis-plan-to-end-too-big-to-fail-2016.pdf.

Fender, I. and U. Lewrick (2016). Adding it all up: the macroeconomic impact of Basel III and outstanding reform issues. Number 591. Basel: Bank for International Settlements. www.bis. orghttps://www.bis.org/publ/work591.pdf.

Firestone, S., A. Lorenc, and B. Ranish (2017, March). An empirical economic assessment of the costs and benefits of bank capital in the US. Finance and Economics Discussion Series 2017(34).

Gambacorta, L. and H. S. Shin (2016). Why bank capital matters for monetary policy. BIS Working Paper No. 558 (ID 2760324), 1-34.

Gambacorta, L. and H. S. Shin (2018, July). Why bank capital matters for monetary policy. Journal of Financial Intermediation 35, 17-29.

Glover, J. (2016). CoCo Turmoil Forces Europe to Act on Surprise Coupon Loss. Bloomberg. 12, March 2016.

Goel, T., U. Lewrick, and A. Mathur (2019, September). Playing it safe: GSIBs after the crisis. BIS Quarterly Review, 55-65.

Gropp, R., T. C. Mosk, S. Ongena, and C. Wix (2016, March). Bank Response to Higher Capital Requirements: Evidence from a Quasi-Natural Experiment. SSRN eLibrary (ID 2877839), 1-82.

Henry, P. (2016). Bank Stress Tests Won't Affect CoCo Payments, ECB's Nouy Says. Bloomberg. June 9, 2016.

Homar, T. and S. J. van Wijnbergen (2017). Bank recapitalization and economic recovery after financial crises. Journal of Financial Intermediation 32, 16-28.

Jensen, T. (2015, June). The Real Effects of Higher Capital Requirements: Evidence from Danish Firm-Level Data. SSRN Electronic Journal (ID 2766374). https://ssrn.com/abstract=2315551. 
Jordà, Ò., B. Richter, M. Schularick, and A. M. Taylor (2017, March). Bank Capital Redux: Solvency, Liquidity, and Crisis. NBER Working Paper Series, 1-55.

Kashyap, A., J. Stein, and S. Hanson (2010). An analysis of the impact of substantially heightened capital requirements on large financial institutions. Booth School of Business, University of Chicago, mimeo 2, 1-47. https://www.hbs.edu/faculty/Pages/item.aspx?num=41199.

Kashyap, A. K., R. G. Rajan, and J. C. Stein (2008). Rethinking capital regulation. In Federal Reserve Bank of Kansas City Symposium on Maintaining Stability in a Changing Financial System, pp. 431-471. Federal Reserve Bank of Kansas City.

Liu, W., J. W. Kolari, T. Kyle Tippens, and D. R. Fraser (2013). Did capital infusions enhance bank recovery from the great recession? Journal of Banking \& Finance 37(12), 5048-5061.

Lubberink, M. J. P. and A. Renders (2018). Are Banks' Below-Par Own Debt Repurchases a Cause For Prudential Concern? Journal of Accounting, Auditing \& Finance 33(1), 1-29.

Mathur, A. (2019). In the dangerzone! Regulatory uncertainty and voluntary bank capital surpluses. Working paper.

Mehran, H. and A. Thakor (2011). Bank capital and value in the cross-section. Review of Financial Studies 24(4), 1019-1067.

Melis, A. and K. Weissenberg (2019, March). EU banks journey towards an enhanced capital framework. London: European Banking Authority. https://eba.europa.eu/documents/10180/ 2259345/EU+banks+journey+towards+an+enhanced+capital+framework++-+March+ 2019.pdf.

Pablo Hernández de Cos (2019). Post-Basel III: time for evaluation. Basel: Bank for International Settlements. https://www.bis.org/speeches/sp191024.htm.

Shotter, J. (2016). Charges to push Deutsche Bank to €6.7bn loss. Financial Times. January 21, 2016.

Steffen, S. (2014). Robustness, validity, and significance of the ECB's asset quality review and stress test exercise. SAFE White Paper Series 23, Research Center SAFE - Sustainable Architecture for Finance in Europe, Goethe University Frankfurt. https://ideas.repec.org/p/zbw/ safewh/23.html.

Thakor, A. V. (2014, December). Bank capital and financial stability: An economic tradeoff or a faustian bargain? Annual Review of Financial Economics 6(1), 185-223.

Vallée, B. (2019, June). Contingent Capital Trigger Effects: Evidence from Liability Management Exercises. The Review of Corporate Finance Studies 8(2), 235-259.

World Bank (2019). "Global Financial Development Report 2019 / 2020: Bank Regulation and Supervision a Decade after the Global Financial Crisis". Washington: World Bank. https: //openknowledge.worldbank.org/bitstream/handle/10986/32595/9781464814471.pdf. 


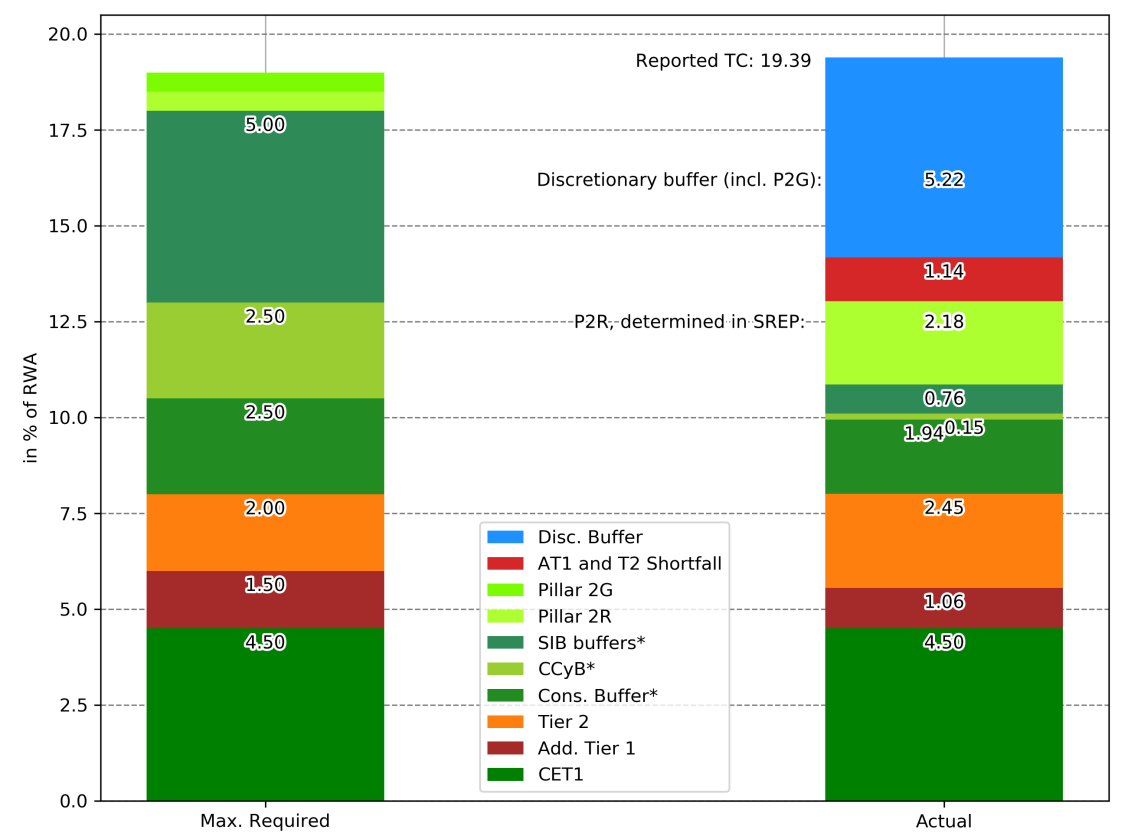

Figure 1: EU Capital requirements and actuals (2018). 
,, , , 
,,,,,,,,, , 
Table 2: Correlations.

\begin{tabular}{|c|c|c|c|c|c|c|c|c|c|c|c|c|c|c|c|}
\hline $\begin{array}{l}\text { Correlations } \\
n=580\end{array}$ & $\begin{array}{l}\text { Reported } \\
\text { CET1 }\end{array}$ & $\begin{array}{l}\text { Discretionary } \\
\text { buffer }\end{array}$ & SREP & $\begin{array}{l}\text { Combined } \\
\text { Buffer }\end{array}$ & Profitability & Z-score & Densities & Size & $\begin{array}{l}\text { Credit } \\
\text { Growth }\end{array}$ & $\begin{array}{l}\mathrm{NPE} \\
\text { ratio }\end{array}$ & $\begin{array}{l}\text { Yields } \\
\text { on AT1 }\end{array}$ & PE ratio & $\begin{array}{l}\text { Market } \\
\text { to Book }\end{array}$ & SSM & Latitude \\
\hline Reported CET1 & 1.00 & 0.69 & -0.05 & 0.32 & 0.26 & 0.24 & -0.38 & -0.01 & -0.05 & -0.35 & -0.36 & -0.02 & 0.28 & -0.23 & 0.43 \\
\hline Disc Buffer & 0.85 & 1.00 & -0.50 & 0.04 & 0.13 & 0.20 & -0.23 & -0.10 & -0.03 & -0.16 & -0.10 & -0.08 & 0.04 & 0.07 & 0.14 \\
\hline SREP requirement & -0.01 & -0.41 & 1.00 & -0.30 & -0.11 & -0.28 & -0.08 & 0.06 & -0.08 & 0.11 & 0.01 & 0.26 & 0.03 & -0.08 & 0.03 \\
\hline Combined Buffer req. & 0.25 & -0.07 & -0.11 & 1.00 & 0.27 & 0.40 & -0.13 & 0.12 & 0.05 & -0.36 & -0.30 & -0.18 & 0.25 & -0.30 & 0.25 \\
\hline Profitability & 0.18 & 0.13 & -0.06 & 0.21 & 1.00 & 0.24 & -0.14 & 0.06 & 0.35 & -0.34 & -0.31 & 0.01 & 0.60 & -0.32 & 0.38 \\
\hline Z-score & 0.19 & 0.18 & -0.25 & 0.29 & 0.29 & 1.00 & 0.48 & -0.27 & 0.05 & 0.30 & -0.03 & 0.06 & 0.16 & -0.08 & -0.11 \\
\hline Densities & -0.39 & -0.28 & -0.10 & -0.14 & -0.14 & 0.49 & 1.00 & -0.55 & -0.06 & 0.71 & 0.37 & 0.00 & -0.19 & 0.11 & -0.52 \\
\hline Size & -0.02 & -0.08 & 0.07 & 0.09 & 0.07 & -0.27 & -0.51 & 1.00 & 0.07 & -0.48 & -0.05 & 0.08 & 0.14 & -0.12 & 0.36 \\
\hline Credit growth & -0.03 & -0.04 & -0.02 & 0.04 & 0.31 & 0.04 & -0.06 & 0.02 & 1.00 & -0.20 & -0.12 & 0.12 & 0.28 & -0.10 & 0.09 \\
\hline NPE ratio & -0.14 & -0.08 & 0.06 & -0.23 & -0.42 & 0.28 & 0.60 & -0.39 & -0.18 & 1.00 & 0.51 & 0.13 & -0.38 & 0.25 & -0.64 \\
\hline Yields on AT1 & -0.13 & -0.06 & 0.01 & -0.14 & -0.04 & 0.07 & 0.21 & -0.18 & -0.06 & 0.32 & 1.00 & -0.18 & -0.32 & 0.28 & -0.26 \\
\hline PE ratio & -0.11 & -0.17 & 0.21 & -0.18 & 0.00 & 0.01 & 0.04 & 0.10 & 0.05 & 0.24 & -0.13 & 1.00 & 0.15 & 0.08 & -0.06 \\
\hline Market to Book & 0.36 & 0.04 & 0.14 & 0.38 & 0.31 & 0.21 & -0.16 & 0.09 & 0.06 & -0.41 & -0.03 & 0.01 & 1.00 & -0.48 & 0.49 \\
\hline SSM & -0.14 & 0.08 & -0.14 & -0.43 & -0.21 & -0.09 & 0.09 & -0.09 & -0.08 & 0.20 & 0.17 & 0.15 & -0.51 & 1.00 & -0.52 \\
\hline Latitude & 0.34 & 0.13 & 0.09 & 0.43 & 0.28 & -0.09 & -0.47 & 0.33 & 0.06 & -0.56 & -0.04 & -0.14 & 0.49 & -0.52 & 1.00 \\
\hline
\end{tabular}

The table presents Pearson (above diagonal) and Spearman correlations (below diagonal) for the main variables, from 99 European Banks over the year 2012-2018. Reported CET1 is the CET1 ratio reported by banks, Discretionary buffer or Disc buffer is the difference between Reported CET1 and Overall Requirement. SREP or SREP requirement is the requirement agreed with the supervisor as an outcome of the Supervisory Review and Evaluation Process. This variable includes P2R, P2A, and similar additional bank-specific requirements obtained from banks' disclosures. Combined Buffer requirement is Overall Requirement minus the SREP requirement, Profitability is the return on equity (ROE) in $\%, Z$-score is $\frac{L R+R O A}{\sigma(R O A)}$, where $L R$ is the leverage ratio and ROA the return on assets, Densities is the ratio of RWAs over Total Assets, Size is the log of Total Assets, Credit Growth is the relative change in credit exposure values over one year in \%, NPE ratio is the ratio of non-performing loans over total loans, Yields on ATl is the mean annual yield on Additional Tier 1 capital instruments, PE ratio is the Price Earnings ratio, for listed banks only, and Market to Book is the ratio of the market capitalisation over the book equity value, ibid. SSM is 1 for banks that are subjected to the Single Supervisory Mechanism. Latitude is the latitude of the bank's headquarters. 
Table 3: Discretionary Buffers and SREP requirements.

\begin{tabular}{|c|c|c|c|c|c|c|c|c|c|c|}
\hline \multirow[b]{2}{*}{ Discretionary Buffer } & \multicolumn{2}{|c|}{ I } & \multicolumn{2}{|c|}{ II } & \multicolumn{2}{|c|}{ III } & \multicolumn{2}{|c|}{ IV } & \multicolumn{2}{|c|}{$\mathrm{V}(\log )$} \\
\hline & $\beta$ & $p$ & $\beta$ & $p$ & $\beta$ & $p$ & $\beta$ & $p$ & $\beta$ & $p$ \\
\hline SREP requirement & -0.89 & 0.00 & -0.84 & 0.00 & -0.82 & 0.00 & -0.85 & 0.00 & -0.54 & 0.00 \\
\hline Combined Buffer req. & -1.10 & 0.00 & -0.47 & 0.00 & -0.51 & 0.00 & -1.51 & 0.00 & -0.79 & 0.01 \\
\hline Density & -22.4 & 0.00 & -13.0 & 0.00 & -13.9 & 0.00 & -45.1 & 0.00 & 0.96 & 0.02 \\
\hline Size & -0.93 & 0.00 & -2.60 & 0.00 & -2.72 & 0.05 & -1.80 & 0.00 & 2.15 & 0.00 \\
\hline Z-score & 0.57 & 0.01 & 0.16 & 0.12 & 0.24 & 0.09 & 1.07 & 0.00 & 0.06 & 0.06 \\
\hline Profitability & -0.03 & 0.34 & 0.02 & 0.05 & 0.02 & 0.14 & -0.09 & 0.00 & 0.01 & 0.08 \\
\hline SSM & -0.88 & 0.14 & & & & & & & & \\
\hline Credit growth & & & & & -1.60 & 0.02 & & & -0.47 & 0.02 \\
\hline Intercept & 31.1 & 0.00 & 45.8 & 0.00 & 46.9 & 0.01 & 48.6 & 0.00 & -7.13 & 0.07 \\
\hline Linear model & \multicolumn{2}{|c|}{ Pooled OLS } & \multicolumn{2}{|c|}{ FE\&TE } & \multicolumn{2}{|c|}{ FE\&TE } & \multicolumn{2}{|c|}{ IV-regression } & \multicolumn{2}{|c|}{ FE\&TE } \\
\hline $\bar{R}^{2}$ & \multirow{2}{*}{\multicolumn{2}{|c|}{$\begin{array}{r}0.48 \\
580\end{array}$}} & \multicolumn{2}{|r|}{0.47} & \multicolumn{2}{|r|}{0.52} & \multicolumn{2}{|r|}{0.17} & \multicolumn{2}{|r|}{0.24} \\
\hline Obs. & & & & 580 & & 423 & & 580 & & 367 \\
\hline & \multicolumn{6}{|c|}{ Latitude } \\
\hline Durbin Score $\left(\chi^{2}\right)$ : & & & & & & & 24.9 & 0.00 & & \\
\hline Wu-Hausman $(F)$ : & & & & & & & 25.6 & 0.00 & & \\
\hline Partial $F$ on the instrument: & & & & & & & 42.6 & 0.00 & & \\
\hline
\end{tabular}

The table presents regression results from a sample of 99 European Banks over the years 2013-2018. Discretionary Buffer is the difference between Reported CET1, i.e. the CET1 or CT1 ratio reported by banks, and Overall Requirement, the sum of all disclosed capital requirements: the CET1 or CT1 requirement, the conservation buffer, any buffer for systemically importance, the countercyclical buffer, and SREP requirements. For years after 2017, this buffer is net of the AT1, Tier 2 shortfall.

$$
\begin{array}{lll}
\text { DiscBuffer }_{i, t} & =\beta_{0}+\beta_{1} \times S R E P_{i, t}+\beta_{2} \times \text { CombBuffer }_{i, t} & + \text { Controls }_{i, t}+\varepsilon_{i, t} \\
\log (\text { DiscBuffer } \times \text { RWA })_{i, t} & =\beta_{0}+\beta_{1} \times S R E P_{i, t}+\beta_{2} \cdot \log (\text { CombBuffer } \times R W A)_{i, t} & + \text { Controls }_{i, t}+\varepsilon_{i, t}
\end{array}
$$

SREP or SREP requirement is the requirement agreed with the supervisor as an outcome of the Supervisory Review and Evaluation Process. This variable includes $\mathrm{P} 2 \mathrm{R}, \mathrm{P} 2 \mathrm{~A}$, and similar additional bank-specific requirements obtained from banks' disclosures. Combined Buffer is Overall Requirement minus the SREP requirement, Density is the ratio of RWAs over Total Assets (in the log model: the log of RWA), Size is the log of Total Assets, Z-score is $\frac{L R+R O A}{\sigma(R O A)}$, where $L R$ is the leverage ratio and $R O A$ the return on assets, Profitability is the return on equity (ROE) in \%, $S S M$ is one for banks that are subjected to the Single Supervisory Mechanism, Credit Growth is the relative change in credit exposure values over one year in $\%, \bar{R}^{2}$ is the coefficient of determination adjusted for degrees of freedom. The regression models rely on $p$-values that account for two-dimensional within-cluster correlation. $F E$ and $T E$ are fixed firm (FE) and time effects (TE) respectively. 
Table 4: Discretionary Buffers and Measures of Risk.

\begin{tabular}{|c|c|c|c|c|c|c|c|c|c|c|}
\hline & \multicolumn{2}{|c|}{$\mathrm{I}$} & \multicolumn{2}{|c|}{ II } & \multicolumn{2}{|c|}{ III } & \multicolumn{2}{|c|}{ IV } & \multicolumn{2}{|c|}{$\mathrm{V}$} \\
\hline Panel A: Z-scores & $\beta$ & $p$ & $\beta$ & $p$ & $\beta$ & $p$ & $\beta$ & $p$ & $\beta$ & $p$ \\
\hline Discretionary Buffer & 0.18 & 0.03 & 0.17 & 0.03 & 0.20 & 0.02 & 0.10 & 0.06 & 0.12 & 0.03 \\
\hline Overall Requirement & 0.15 & 0.10 & & & & & & & & \\
\hline SREP requirement & & & 0.13 & 0.26 & 0.25 & 0.01 & 0.16 & 0.03 & 0.19 & 0.02 \\
\hline Combined Buffer req. & & & 0.21 & 0.06 & 0.18 & 0.06 & 0.19 & 0.04 & 0.21 & 0.02 \\
\hline Size & -6.76 & 0.00 & -6.77 & 0.00 & -4.13 & 0.00 & -4.33 & 0.00 & -3.48 & 0.00 \\
\hline NPE ratio & & & & & -0.04 & 0.63 & -0.01 & 0.89 & -0.05 & 0.48 \\
\hline Profitability & & & & & & & 0.09 & 0.00 & 0.08 & 0.00 \\
\hline Credit growth & & & & & & & & & -1.23 & 0.09 \\
\hline Intercept & 85.9 & 0.00 & 85.7 & 0.00 & 55.5 & 0.00 & 58.1 & 0.00 & 48.1 & 0.00 \\
\hline Linear model & \multicolumn{2}{|c|}{ FE\&TE } & \multicolumn{2}{|c|}{ FE\&TE } & \multicolumn{2}{|c|}{ FE\&TE } & \multicolumn{2}{|c|}{ FE\&TE } & \multicolumn{2}{|c|}{ FE\&TE } \\
\hline $\bar{R}^{2}$ & & 0.34 & & & \multicolumn{2}{|c|}{$\begin{array}{l}\text { FE\&TE } \\
0.15\end{array}$} & \multicolumn{2}{|c|}{0.40} & \multicolumn{2}{|c|}{0.36} \\
\hline Obs. & \multicolumn{2}{|r|}{581} & \multicolumn{2}{|r|}{581} & & 429 & \multicolumn{2}{|r|}{429} & \multicolumn{2}{|r|}{413} \\
\hline Panel B: Yields on AT1 & & & $\beta$ & $p$ & $\beta$ & $p$ & $\beta$ & $p$ & $\beta$ & $p$ \\
\hline Discretionary Buffer & & & -0.09 & 0.01 & -0.32 & 0.01 & -0.26 & 0.02 & -0.27 & 0.01 \\
\hline Overall Requirement & & & -0.12 & 0.10 & & & & & & \\
\hline SREP requirement & & & & & -0.02 & 0.85 & 0.05 & 0.67 & 0.07 & 0.56 \\
\hline Combined Buffer req. & & & & & -0.60 & 0.01 & -0.36 & 0.01 & -0.38 & 0.00 \\
\hline Size & & & -0.59 & 0.79 & -1.11 & 0.03 & -0.63 & 0.02 & -0.62 & 0.03 \\
\hline NPE ratio & & & & & & & 0.34 & 0.14 & 0.36 & 0.11 \\
\hline Credit growth & & & & & & & & & 1.84 & 0.64 \\
\hline Intercept & & & 16.7 & 0.55 & 27.2 & 0.00 & 17.8 & 0.00 & 17.68 & 0.00 \\
\hline Linear model & & & \multicolumn{2}{|c|}{ FE\&TE } & \multicolumn{2}{|c|}{ FE\&TE } & \multicolumn{2}{|c|}{ FE\&TE } & \multicolumn{2}{|c|}{ FE\&TE } \\
\hline $\bar{R}^{2}$ & & & \multicolumn{2}{|r|}{0.007} & & 0.084 & & 0.134 & & 0.138 \\
\hline Obs. & & & & 205 & & 205 & & 176 & & 172 \\
\hline Panel C: Densities & $\beta$ & $p$ & $\beta$ & $p$ & $\beta$ & $p$ & $\beta$ & $p$ & $\beta$ & $p$ \\
\hline Discretionary Buffer & -0.009 & 0.00 & -0.008 & 0.00 & -0.009 & 0.00 & -0.009 & 0.00 & -0.009 & 0.00 \\
\hline Overall Requirement & -0.008 & 0.00 & & & & & & & & \\
\hline SREP requirement & & & -0.007 & 0.00 & -0.006 & 0.00 & -0.006 & 0.00 & -0.007 & 0.00 \\
\hline Combined Buffer req. & & & -0.010 & 0.00 & -0.008 & 0.00 & -0.009 & 0.00 & -0.009 & 0.00 \\
\hline Size & -0.164 & 0.00 & -0.163 & 0.00 & -0.195 & 0.00 & -0.195 & 0.00 & -0.200 & 0.00 \\
\hline NPE ratio & & & & & 0.004 & 0.02 & 0.004 & 0.02 & 0.004 & 0.04 \\
\hline Profitability & & & & & & & 0.0003 & 0.19 & 0.0004 & 0.09 \\
\hline Credit growth & & & & & & & & & -0.0135 & 0.27 \\
\hline Intercept & 2.486 & 0.00 & 2.467 & 0.00 & 2.811 & 0.00 & 2.820 & 0.00 & 2.885 & 0.00 \\
\hline Linear model & FE\& & & & & & & & & FE & \\
\hline $\bar{R}^{2}$ & & 0.30 & & 0.30 & & 0.37 & & 0.38 & & 0.37 \\
\hline Obs. & & 580 & & 580 & & 429 & & 429 & & 413 \\
\hline
\end{tabular}

The table presents regression results from a sample of 99 European Banks over the years 2013-2018. Z-score is $\frac{L R+R O A}{\sigma(R O A)}$, where $L R$ is the leverage ratio and $R O A$ the return on assets, Yields on $A T 1$ is the mean annual yield on Additional Tier 1 capital instruments, Density, Densities is the ratio of RWAs over Total Assets, Discretionary Buffer is the difference between Reported CET1, i.e. the CET1 ratio reported by banks. For years after 2017, this buffer is net of the AT1, Tier 2 shortfall.Overall Requirement, the sum of all disclosed capital requirements: the base CET1 or CT1 requirement, the conservation buffer, any buffer for systemically importance, the countercyclical buffer, and SREP requirements. SREP or SREP requirement is the requirement agreed with the supervisor as an outcome of the Supervisory Review and Evaluation Process. This variable includes P2R, P2A, and similar additional bank-specific requirements obtained from banks' disclosures. Combined Buffer is Overall Requirement minus the SREP requirement, Size is the log of Total Assets, NPE ratio is the ratio of non-performing loans over total loans, Profitability is the return on equity (ROE) in \%, Credit Growth is the relative change in credit exposure values over one year in \%, and $\bar{R}^{2}$ is the coefficient of determination adjusted for degrees of freedom. The regression models rely on $p$-values that account for two-dimensional within-cluster correlation. All models are panel data models controlling for fixed firm (FE) and time effects (TE). 
Table 5: Discretionary bank buffers and the impact of a large shock.

\begin{tabular}{lrr}
\hline Dependent variable: share price drop March 2020 & \\
\hline & $\beta$ & $p$ \\
\hline Discretionary Buffer & -0.012 & 0.03 \\
SREP requirement & -0.016 & 0.16 \\
Combined Buffer req. & -0.003 & 0.81 \\
Density & -0.068 & 0.62 \\
Size & 0.006 & 0.58 \\
SSM & 0.080 & 0.02 \\
Credit growth & -0.129 & 0.05 \\
NPE ratio & 0.004 & 0.05 \\
Intercept & 0.373 & 0.07 \\
$\bar{R}^{2}$ & & 0.445 \\
Obs. & 50
\end{tabular}

The table presents regression results from a sample of 50 listed European Banks (2018). The dependent variable is the share price drop from February 19 to March 13, 2020, multiplied by -1: price declines have a positive sign and price increases a negative sign. Discretionary Buffer is the difference between Reported CET1, i.e. the CET1 ratio reported by banks and Overall Requirement, the sum of all disclosed capital requirements: the base CET1 or CT1 requirement, the conservation buffer, any buffer for systemically importance, the countercyclical buffer, and SREP requirements. For years after 2017, this buffer is net of the AT1, Tier 2 shortfall.Density is the ratio of RWAs over Total Assets (in the log model: the log of RWA), Size is the log of Total Assets, $Z$-score is $\frac{L R+R O A}{\sigma(R O A)}$, where $L R$ is the leverage ratio and $R O A$ the return on assets, $S S M$ is one for banks that are subjected to the Single Supervisory Mechanism, Credit Growth is the relative change in credit exposure values over one year in \%, NPE ratio is the ratio of non-performing loans over total loans, $\bar{R}^{2}$ is the coefficient of determination adjusted for degrees of freedom. The regression models rely on $p$-values that account for two-dimensional within-cluster correlation. 
Table 6: Responses to stress test results.

\begin{tabular}{lrrrrrr}
\hline & \multicolumn{1}{c}{ All } & \multicolumn{2}{c}{$<2016$} & \multicolumn{2}{c}{$\geq 2016$} \\
\hline Discretionary Buffer & $\beta$ & $p$ & $\beta$ & $p$ & $\beta$ & $p$ \\
\hline Stressed CET1 (-) & -0.42 & 0.00 & -0.26 & 0.02 & -0.53 & 0.00 \\
SSM & -4.78 & 0.01 & -0.81 & 0.64 & -7.64 & 0.00 \\
Stressed CET1 (-) $\times$ SSM & 0.47 & 0.01 & 0.09 & 0.64 & 0.76 & 0.00 \\
SREP requirement & -0.90 & 0.00 & -1.03 & 0.00 & -0.69 & 0.00 \\
Adj. Comb. Buff. req. & -0.82 & 0.00 & -0.89 & 0.00 & -0.74 & 0.00 \\
Density & -10.2 & 0.00 & -10.7 & 0.00 & -9.75 & 0.00 \\
Size & -0.77 & 0.00 & -0.61 & 0.00 & -1.07 & 0.00 \\
Profitability & 0.00 & 0.92 & -0.03 & 0.33 & 0.06 & 0.03 \\
NPE ratio & 0.23 & 0.00 & 0.18 & 0.00 & 0.32 & 0.00 \\
Credit growth & -5.00 & 0.01 & -4.56 & 0.01 & -8.86 & 0.05 \\
Intercept & 22.1 & 0.00 & 18.8 & 0.00 & 26.3 & 0.00 \\
Linear model & \multicolumn{2}{c}{ TE } & & TE & & TE \\
$\bar{R}^{2}$ & & 0.78 & & 0.72 & & 0.87 \\
Obs. & & 292 & & 153 & & 139 \\
\hline
\end{tabular}

The table presents regression results from a sample of 87 European Banks over the years 2014-2018. Note the sample contains no observations from Bulgaria, Estonia, and Romania. Discretionary Buffer is the difference between Reported CET1, i.e. the CET1 ratio reported by banks and Overall Requirement, the sum of all disclosed capital requirements: the $4.5 \%$ CET requirement, the conservation buffer, any buffer for systemically importance, the countercyclical buffer, and SREP requirements. For years after 2017, this buffer is net of the AT1, Tier 2 shortfall. Stressed CET1 is the CET1 capital requirement from the EBA stress test, two years out, under the adverse scenario. SSM denotes sample banks that are subjected to the Single Supervisory Mechanism.

$$
\text { DiscBuffer }=\beta_{0}+\beta_{1} \cdot \text { CET }^{\text {Stress }}+\beta_{2} \cdot S S M+\beta_{3} \cdot \text { CET }^{\text {Stress }} \cdot S S M+\beta_{4} \cdot \operatorname{SREP}+\beta_{5} \cdot \text { CombBuffer }^{\prime}+\text { Controls }+\varepsilon
$$

SREP or SREP requirement is the requirement agreed with the supervisor as an outcome of the Supervisory Review and Evaluation Process. This variable includes P2R, P2A, and similar additional bank-specific requirements obtained from banks' disclosures. Adj. Comb. Buff. req. is the Combined Buffer requirement minus the Stressed CET1, Density is the ratio of RWAs over Total Assets, Size is the log of Total Assets \%, Profitability is the return on equity (ROE) in \%, NPE ratio is the ratio of non-performing loans over total loans. Credit Growth is the relative change in credit exposure values over one year in $\%$, and $\bar{R}^{2}$ is the coefficient of determination adjusted for degrees of freedom. The regression models rely on $p$-values that account for two-dimensional within-cluster correlation. All models are panel data models controlling for time effects (TE). 
Table 7: Responses to stress test results - difference in differences.

\begin{tabular}{|c|c|c|c|c|}
\hline \multirow[t]{3}{*}{ Dependent variable: } & \multicolumn{4}{|c|}{ Discretionary Buffer } \\
\hline & \multicolumn{2}{|c|}{ I } & \multicolumn{2}{|c|}{ II } \\
\hline & $\beta$ & $p$ & $\beta$ & $p$ \\
\hline SSM & -2.51 & 0.09 & -0.87 & 0.70 \\
\hline Stressed CET1 & -0.30 & 0.07 & -0.42 & 0.04 \\
\hline SSM $\times$ Stressed CET 1 & 0.26 & 0.13 & 0.15 & 0.46 \\
\hline Y2016 & 0.31 & 0.88 & -0.32 & 0.89 \\
\hline $\mathrm{SSM} \times \mathrm{Y} 2016$ & -1.25 & 0.59 & -1.92 & 0.43 \\
\hline Stressed CET $1 \times$ Y 2016 & 0.02 & 0.93 & 0.08 & 0.68 \\
\hline SSM $\times$ Stressed CET $1 \times$ Y 2016 & 0.17 & 0.37 & 0.22 & 0.28 \\
\hline Y2018 & 4.50 & 0.10 & 0.95 & 0.71 \\
\hline $\mathrm{SSM} \times \mathrm{Y} 2018$ & -9.31 & 0.00 & -4.54 & 0.05 \\
\hline Stressed CET1 $\times$ Y 2018 & -0.40 & 0.05 & -0.11 & 0.30 \\
\hline SSM $\times$ Stressed CET $1 \times$ Y 2018 & 0.73 & 0.00 & 0.35 & 0.06 \\
\hline SREP requirement & -0.94 & 0.00 & -0.84 & 0.00 \\
\hline Profitability & 0.01 & 0.66 & 0.03 & 0.11 \\
\hline Density & -9.90 & 0.00 & -13.4 & 0.00 \\
\hline Size & -0.73 & 0.00 & -0.64 & 0.00 \\
\hline Adj. Comb. Buff. req. & -0.78 & 0.00 & -0.83 & 0.00 \\
\hline NPE ratio & 0.20 & 0.00 & 0.12 & 0.00 \\
\hline Credit growth & -5.41 & 0.00 & -2.97 & 0.01 \\
\hline Non-stressed bank $\left(D^{N S}\right)$ & & & 7.67 & 0.00 \\
\hline Intercept & 20.45 & 0.00 & 20.93 & 0.00 \\
\hline $\bar{R}^{2}$ & & 0.77 & & 0.61 \\
\hline Obs. & & 292 & & 413 \\
\hline
\end{tabular}

The table presents regression results from a sample Ruropean Banks over the year 2014-2018. Model I contains no observations from Bulgaria, Estonia, and Romania, reducing the number of sample banks to 87. Model II includes observations of all 99 banks. Discretionary Buffer is the difference between Reported CET1, i.e. the CET1 ratio reported by banks and Overall Requirement, the sum of all disclosed capital requirements: the $4.5 \%$ CET1 requirement, the conservation buffer, any buffer for systemically importance, the countercyclical buffer, and SREP requirements. For years after 2017, this buffer is net of the AT1, Tier 2 shortfall. SSM denotes sample banks that are subjected to the Single Supervisory Mechanism. Stressed CET1 is the CET1 capital requirement from the EBA stress test, two years out, under the adverse scenario. SREP or SREP requirement is the requirement agreed with the supervisor as an outcome of the Supervisory Review and Evaluation Process. This variable includes P2R, P2A, and similar additional bank-specific requirements obtained from banks' disclosures. Profitability is the return on equity (ROE) in \%, Density is the ratio of RWAs over Total Assets, Size is the log of Total Assets \%, Adj. Comb. Buff. req. is the Combined Buffer requirement minus the Stressed CET1, NPE ratio is the ratio of non-performing loans over total loans, Credit Growth is the relative change in credit exposure values over one year in \%, and Non-stressed.bank or $D^{N S}$ is an indicator variable set to the value of 1 for observations from banks not participating in the stress test. The reason to include this indicator variable is that the model now includes all sample observations, not only the observations from banks participating in the EBA stress test. For Model II, $C E T 1^{\text {Stress }}$ has a value of zero for observations from banks not participating in the stress test. These 'zero' observations thus complement $D^{N S}$, which is set to one for these (non-participating) banks. $\bar{R}^{2}$ is the coefficient of determination adjusted for degrees of freedom. The regression models rely on $p$-values that account for two-dimensional within-cluster correlation. 